\title{
ANTI-ANALGESIC ACTIVITY OF METHANOLIC LEAF EXTRACT OF WATTAKAKA VOLUBILIS (LINN. F.) BENTH EX. HOOK F. (ASCLEPIADACEAE) - A RARE AND THREATENED MEDICINAL PLANT
}

\author{
Udhayasankar,M.R ${ }^{1 *}$., U. Danya ${ }^{2}$ and K. Arumugasamy ${ }^{1}$ \\ 1Department of Botany, Kongunadu Arts and Science College (Autonomous), Coimbatore-641 029. \\ ${ }^{2}$ Department of Botany, Nirmala College for Women, Coimbatore-641 018. \\ *E.mail: udhaybio2010@gmail.com
}

\begin{abstract}
The present study, investigates themethanolicleaves extract of Wattakaka volubilis (Family: Asclepiadaceae) designated as 'the extract' was evaluated for analgesic activity in mice. The analgesic activity was evaluated in mice models. In the acute toxicity study, it was found that the extract was non-toxic up to $1000 \mathrm{mg} / \mathrm{kg}$, p. o. The extract (150, 200 and $400 \mathrm{mg} / \mathrm{kg}$, p. o.) was found to possessanalgesic activities in a dose-dependent manner and the effect was comparable with thatproduced by the standard drug, Diclofenac sodium.
\end{abstract}

Keywords: Wattakaka volubilis, analgesic activity, leaves methanolic extract.

\section{INTRODUCTION}

Wattakaka volubilis belongs to the family Asclepiadaceaeit is used as an alternate source of the Ayurveda drug Murva, the accepted botanical source of which is Marsdenia tenacissima (Roxb.) Moon (Yoganarasimhan, 2000). Murva are used in various diseases like anaemia, fever, diabetes, stomach disorders, typhoid, urinaryinfections and cough (Kolammal, 1978). Leaf juice is used to cure sprain. Leaf paste is taken along with pepper to treat dyspepsia and leaf powder taken orally along with cow's milk is reported to have anti-diabetic activity. It is also used to treat rheumatic pain, cough, fever, severe cold, boils and abscesses. Bark paste is taken along with hot milk for urinary problems. $W$. volubilis is used in the treatment of scorpion and snake bites (Sanyasi et al., 2008; Kumar et al., 2007).

\section{MATERIALS AND METHODS}

\subsection{Plant collection and identification}

The plant Wattakaka volubilis was collected from Velliangiri Hills, a part of Western Ghats Coimbatore, Tamil Nadu. India. The plant was identified andauthenticated by a plant taxonomist.

\subsection{Extraction of the plant material}

About $250 \mathrm{~g}$ of freshly collected sample of Wattakaka volubilis (leaf) was separately washed 23 times with water followed by distilled water and shade dried. All the dried parts were pulverized by mechanical grinder (willey mill) to get the powder through 100 mess sieve and then stored in a refrigerator. It was extracted by cold extraction method with methanol. The extracts were concentrated in a rotary evaporator to yield a syrupy residue and used for all the phytochemical analysis and pharmacological activity.

\subsection{Tail-flick method}

The antinociceptive effect of the test substances was determined by the hot tail flick method described by Sewell and Spencer (Sewell and Spencer, 1976). One to two $\mathrm{cm}$ of the tail of mice was immersed in warm water bath (Swan scientific instruments) kept constant at $55 \pm 1^{\circ} \mathrm{C}$. The reaction time was the time taken by the mice to deflect their tails. The first reading is discarded and the reaction time was taken as a mean of the next two readings. Balb-C mice were randomly divided into five groups (six in each). Mice of group I received normal saline (0.1 ml/10 g, p. o.) group II received Diclofenac sodium $(150 \mathrm{mg} / \mathrm{kg}$, p. o.) and groups III, IV and V received 150, 200 and $400 \mathrm{mg} / \mathrm{kg}$, p. o. of the extract, respectively. Thirty minutes later, the tail was immersed in the water bath and the tail flick response was recorded. The same experiments were repeated after 60 minutes and 120 minutes again.

\subsection{Statistics}

Data are presented as arithmetic mean \pm S.E.M of at least six experiments. Statistical analysis was performed by one-way analysis of variance (ANVOA) followed by Dunnett's test or by Student's paired t-test. 'P' value of $<0.05$ was considered as statistically significant.

\section{RESULTS AND DISCUSSION}

It was found that the methanolic leaf extract was non-toxic up to $1000 \mathrm{mg} / \mathrm{kg}$, p. o. body weight up 
to 24 hours. Thus one tenth of it, i.e, $1000 \mathrm{mg} / \mathrm{kg}$, p. o. was taken as the initial starting dose and the other two selected doses were $150 \mathrm{mg} / \mathrm{kg}$, p. o. and 200 $\mathrm{mg} / \mathrm{kg}$, p. o., respectively.

The leaves methanolic extract of $W$. volubilis produced a dose-dependent analgesic activity in the model and the effect produced by $400 \mathrm{mg} / \mathrm{kg}$, p. o. of the extract was compared to the standard drug Diclofenac sodium (Table 1). Pain is 'an unpleasant sensory and emotional experience associated with actual or potential tissue damage, or described in terms of such damage' (Nicholas and Moore, 2009). The drug that reduces the nociceptive response indicated by cutaneous thermic stimuli in the hot plate test might exhibit central analgesic properties or supraspinal analgesia (Matheus et al., 2005). In tail flick test, the root extract of $P$. corymbosa produced slower onset of antinociceptive action than the aerial extract. The tail flick model is considered specific test for evaluation of the central pain (Marchioro et al., 2005) at spinal levels (Wong et al., 1994). In case of analgesic study, tail flick method, it showed time- and dose-dependent analgesic activities. The extract also produced a significant antipyretic effect inthe brewer's yeast-induced pyrexia model in rat.

Table 1. Effect of Wattakaka volubilis leaves methanolic extract on thermal nociception in mice (Tail flick method)

\begin{tabular}{|c|c|c|c|c|}
\hline \multirow{3}{*}{ Drug } & \multirow{3}{*}{ Dose } & \multicolumn{3}{|c|}{ Min. after treatment } \\
\hline & & \multicolumn{3}{|c|}{ Response in $s$ (mean \pm S. E. M) } \\
\hline & & 30 & 60 & 90 \\
\hline Normal saline & $0.9 \mathrm{mg} / \mathrm{dl}$ & $3.1 \pm 0.20$ & $4.2 \pm 0.51$ & $3.0 \pm 0.21$ \\
\hline Diclofenac sodium & $10 \mathrm{mg} / \mathrm{kg}$ & $4.2 \pm 0.51$ & $5.0 \pm 0.15^{*}$ & $5.4 \pm 0.40^{*}$ \\
\hline Extract & $150 \mathrm{mg} / \mathrm{kg}$ & $3.1 \pm 0.30^{*}$ & $3.6 \pm 0.31 *$ & $3.8 \pm 0.52^{*}$ \\
\hline Extract & $200 \mathrm{mg} / \mathrm{kg}$ & $2.6 \pm 0.31^{*}$ & $3.0 \pm 0.22 *$ & $3.0 \pm 0.21 *$ \\
\hline Extract & $400 \mathrm{mg} / \mathrm{kg}$ & $4.1 \pm 0.50 *$ & $4.3 \pm 0.60 *$ & $4.8 \pm 0.56^{*}$ \\
\hline
\end{tabular}

The values are expressed as Mean \pm SEM; $n=6$ animals in each group.Data were analysed by Tukey-Kramer multiple comparison test.

\section{CONCLUSION}

It can conclude from present study that $W$. volubilis leaves methanolic extract can be used for development ofstandardized herbal therapeutic formulation for analgesic activity conditions.

\section{REFERENCES}

Kolammal, M. (1978).Pharmacognosy of Ayurvedic Drugs Series-1,Ayurveda Research Institute, Trivandrum.

Kumar, P., Ayyanar, M., and Ignacimuthu, S. (2007). Medicinal plantsused by Malasar tribes of Coimbatore district, Tamil Nadu. Indian J.Trad. Know. 6: 579-582.

Marchioro, M., M.F.A. Blank, R.H.V. Mourao and A.R. Antoniolli.(2005). Evauation of the antinocieptive properties from BrillantaisiapalisotiiLindau.stems extract. J.Ethnopharmcol., 102: 377-381.

Matheus, M.E., Berrondo, L.F., Vietas, E.C., Menzes, F.S. and P.D. Fernandes.(2005). Evaluation of the Antinocieptive properties from BrillantaisiapalisotiiLindau.stems extract. J. Ethnopharmcol., 102: 377-381.

Nicholas and N.D. Moore.(2009). In search of an ideal analgesic for common acute pain.AcutePain, 11: 129-137.

Sanyasi, R. M. L., Verma, Y. N. R., and Kumar, V. (2008). Effect of Wattakaka volubilis leaf juice and lime on sprains. Ethnobot. Leaflets12: 217226.

Sewell, R.D. and P.S. Spencer. (1976)Antinociceptiveactivity of narcotic agonist and partial agonistanalgesics and other agents in the tailimmersiontest in mice and rats.Neuropharmacol. 5:683-688.

Wong, C.H., P. Day, J. Yarmush, W. Wu and U.K. Zbuzek.(1994). Nifedipine- induced analgesic after eoidural injections in rats. Aneasthesia and Analgesic, 79: 303-306.

Yoganarasimhan, S.N. (2000). Medicinal Plants of India-Tamil Nadu,Cyber Media, Bangalore. 